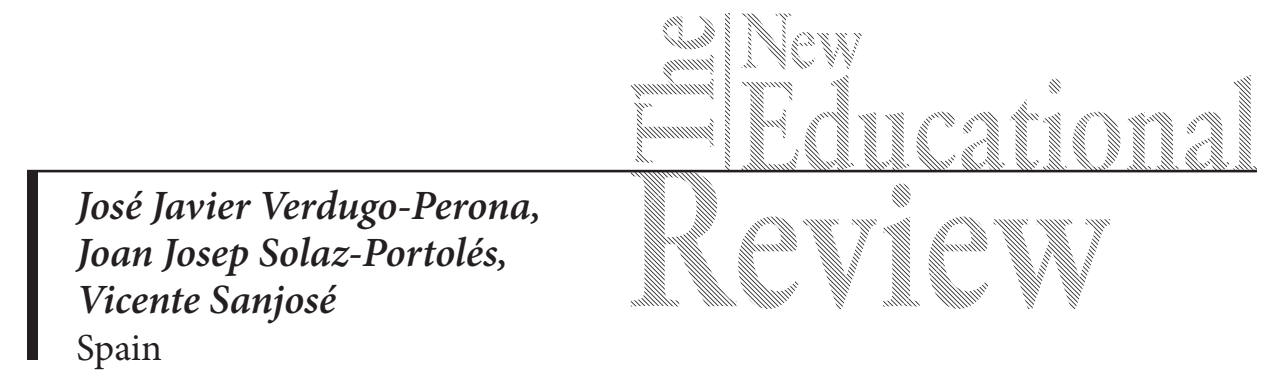

\title{
Is Digital Literacy Improving Science Education?
}

\begin{abstract}
Mass media, and especially digital media, have become an important tool of literacy and have increased their use in classrooms for educational purposes. This is of great interest in scientific literacy and Brossard and Shanahan (2006) developed an instrument to evaluate the understanding of scientific terms and basic science concepts. In this quantitative study we analyse the relationship between Spanish digital mass media and scientific literacy in pre-service primary teachers $(\mathrm{N}=189)$. Results showed that these university students have a term knowledge level lower than the one found by Brossard and Shanahan in the USA. On the other hand, conceptual knowledge was not correlated at all to the term frequency in the Spanish digital newspapers considered. The conclusions suggest that participants do not use digital newspapers to improve their science education so a change in students' use of those digital media from ludic to educational purposes is needed.
\end{abstract}

Keywords: science education, mass media, digital media, scientific literacy, media literacy, pre-service primary teachers, education and media, scientific knowledge

\section{Introduction}

Mass media are frequently considered as important tools of literacy, not only in informal or non-formal contexts (Ingle, 1974; Aparici, 2005), but also in educational formal contexts like classrooms (López, 2003; Wellington, 1991). On the other hand, the dominance of technology in our era has promoted socio-cultural changes that directly affect education and make it necessary to deal with technological progress in schools, encouraging the ability to participate in the utilization of technology as a cultural element. (Kožuchová, 2010). ICT have improved citizens' access to information and have fostered communication in such a way 
that experts refer to media literacy to account for people's ability to access, analyse, assess and produce electronic media as well as printed media (Aufderheide \& Firestone, 1993; Martinsson, 2009; Wilson et al., 2011, p.16).

In the last years, traditional media have used the Internet as a new channel for diffusion purposes among the younger generation. Most newspapers offer digital versions with the advantage of immediacy to their readers. Readers' preferences are changing so fast that some authors have pointed out that these digital channels will soon substitute the traditional ones (Casero-Ripollés, 2012).

However, accessing information and facilitating citizens' communication does not guarantee their education. High levels of media literacy could be associated with low instructional levels and thus with limited possibilities for personal development or social participation in important decisions.

\section{Scientific literacy through mass media}

Optimizing the mass media use in the classroom for educational purposes leads to an emergent and very interesting educational field (Brown, 1998). Experts refer to it as education through mass media. Using mass media with educational purposes allowed teachers to deal with daily questions in order to create reflective citizens able to face the big world-wide problems and actively engaged in decision processes.

Even though some researchers have pointed out teachers' low use of mass media to reach their educational goals (Ronda, 2002), the new generations of teachers frequently use daily news to bring world problems into the classroom (Hobbs \& Jensen, 2009), in this way linking education to real life situations. An important part of citizens' education is scientific literacy, strongly associated with basic science education goals (Gil \& Vilches, 2006). Scientific literacy (...) is seen as a civic competency required for rational thinking about science in relation to personal, social, political, economic problems, and issues that one is likely to meet throughout life (Hurd, 1998, p. 410).

More and more science teachers use mass media as an educational tool, especially those in digital format. For instance, Alvarez (2007) proved the effectiveness of using newspapers in the classroom comparing an alternative instructional methodology to another, traditional one based on expositive procedures. Environmental attitudes and concept knowledge, as well as the knowledge of environmental problems were evaluated in pre-service primary teachers. Statistical tests showed that the experimental group scored significantly higher than the control group in concept knowledge and environmental attitudes.

Taking into account the increasing interest of mass media in the citizens' scientific literacy, Brossard and Shanahan (2006) developed an instrument to evaluate 
the level of knowledge in one of Miller's scientific literacy dimensions: understanding of scientific terms and basic science concepts. These authors focused on scientific terms or concepts very frequent in mass media, which citizens in general should know. First, 185 terms were randomly selected from the Oxford Dictionary of Sciences (Isaacs, Daintith, \& Martin, 1999). Next, each of these terms was classified according to their level of presence in the most important international newspapers in the world. For that purpose they used the Lexis-Nexis database (www.lexisnexis.com). Finally, Brossard and Shanahan selected the most frequent terms in these newspapers and then built a 31-item questionnaire. Each item consists of a sentence defining one of the concepts (or terms) in a standard scientific way. The answer has to be provided by filling in the blank with the particular term. The questionnaire was validated in the USA using a sample of 120 university students of science and social university grades. Results were compared to other results obtained using the Science National Foundation instrument. This comparison showed a positive relationship between the scientific literacy associated with mass media terms and the scientific literacy associated with the classroom, when controlling for age, gender and level of education in science. However, there was no clear evidence of the relationship between the level of newspapers use or TV exposition and the level of scientific literacy.

\section{Aims and hypotheses}

In this paper we aimed at studying the relationship between Spanish digital mass media and scientific literacy in pre-service primary teachers. In order to reach this goal, we will develop three tasks:

T1.-We will use the Brossard and Shanahan instrument (MSL; cf. Appendix) to obtain individual scores of knowledge on basic scientific terms present in important international newspapers. In that way, we can assess the level of scientific literacy among Spanish educated adults, non-specialists in science.

T2.-We will account for the presence of scientific terms in important Spanish digital newspapers. For that purpose, we will explore digital newspapers to obtain the scientific terms frequency by selecting the news with scientific content including each of the terms in MSL.

T3.-Finally, we have to associate the occurrence of scientific terms in digital newspapers with the level of term knowledge among the considered population. We will use statistics to assess the significance of the relationship between term frequency and term knowledge. 
Our hypotheses can be formulated as follows:

H1: Pre-service primary teachers are educated people as university students should be. Therefore, if we considered only basic scientific terms (concepts) frequent in mass media, those students would show a high level of knowledge and thus a high level of scientific literacy.

H2: If digital newspapers are considered by students as a source of science content information, then the more frequent a term or concept is in those newspapers, the higher the knowledge among the participants of this term.

From the above ideas we can infer that citizens' scientific literacy could be improved if primary teachers learnt how to use mass media with educational purposes. Actual pre-service primary teachers are usually young university students presenting a high level of mass media literacy. In addition, even though they are not specialists in science, they are supposed to be educated people with basic science knowledge as they have studied several courses on this subject. As young people in a developed western country, they are digitally literate students, and so online newspapers as well as social networking sites could become sources of scientific information in addition to books and teachers in the classroom.

\section{Research Sample}

A total of one hundred eighty nine male and female undergraduate students in the third year of the pre-service primary teacher training course answered the questionnaire. The University was placed in one of the main Spanish cities. The grade is based on EU guidelines for university degrees. The students' ages ranged from 19 to 52 but, as Figure 1 shows, $90 \%$ of the study population were students aging 18 to 25 , and $64 \%$ were $20-22$ years old.

\section{Procedure to obtain the MSL data}

The instrument developed by Brossard and Shanahan (MSL) was translated into Spanish without any suppression or arrangement. It was administered to every intact group of participants in normal class sessions. Only 20 min were needed for the 31 items of 'filling-in the blanks' nature. Instructions were delivered in a different sheet and they were read aloud. After resolving a few minor doubts, the MSL instrument was delivered to students. Every single item was scored as 0 (error or no answer) or 1 (correct answer). The possible maximum score was 31 . For every participant the MSL mean score was obtained (between 0 and 1 ). When it was considered appropriate, mean scores for every item in the sample were also computed. 
Figure 1. Age distribution in the sample

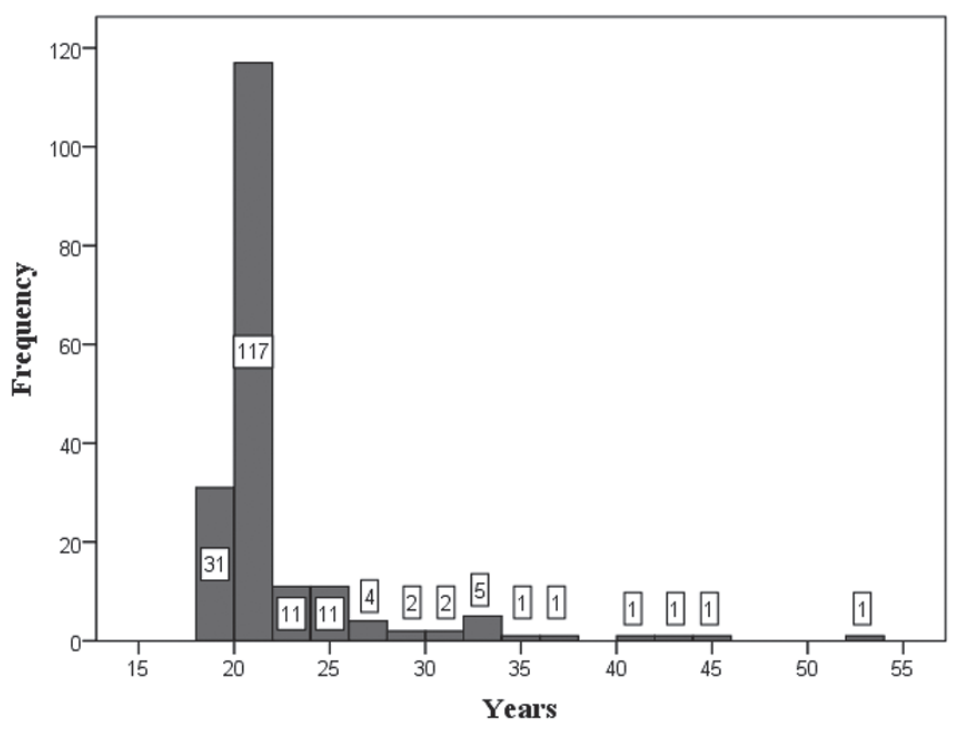

\section{Term frequency in Spanish digital newspapers}

The MSL scientific literacy test uses the $5 \%$ most cited scientific and technical terms in "major newspapers" as reported by Lexis-Nexis database. However, how frequent are these terms in Spanish digital media? To answer this question, we carried out a search of every one of these terms in the three main online digital Spanish newspapers. The selection of the digital newspapers was made according to the data provided by the ComsCore company (http://www.comscore.com), which measures and analyses the audience of digital media. These data were also published in several digital media (público.es and elmundo.com). In February 2014, the digital newspapers in Spain with the highest level of readership were ElMundo.es, ElPais.com and ABC.es. Therefore, the question asked before is simplified now: How frequent are the terms in the MSL questionnaire in these three Spanish digital newspapers?

We established a time interval to keep terms searching in reasonable boundaries. Taking into account the typical age in our sample, we chose a 5 -year window for this interval because five years ago the youngest students in our sample became adults and started to show interest in information. This period covers the last five years of news stories, from January 2009 to December 2013. 
Some potential problems that might influence the results were identified. Brossard and Shanahan (2006) excluded some ambiguous terms from their study. In the same way, when we translated some terms into Spanish they became polysemic, as they could be used in contexts other than the scientific one. For instance, Luna ("Moon") can be the Earth's satellite or a Spanish surname; "Tornado" in Spanish is also a verbal form having the meaning "(has) become", "(has been) transformed", etc. We did not exclude any term but searched carefully in the digital newspapers to identify news including the undesired meaning.

There were important differences among the search engines provided by each digital newspaper. These differences implied different strategies and procedures to exclude inappropriate meanings from the corpus.

"ABC.com»: This search engine allowed for careful search. The search depended on whether the term had other meaning apart from the scientific one or not. If so, the term was introduced as a keyword and one or two additional "neighbour" words were introduced to better delimit the context (e.g. "ray" was searched together with "storm" and "thunder"). If the term had a unique scientific meaning (e.g. "protein"), we did a simple search using the specific term as a keyword. The news was ordered by relevance, based on the position of the searched word on the text, and date. Only the national edition was considered but not the local or regional ones.

«Elmundo.es»: This newspaper has an advanced search engine, but in contrast to the previous case, it is not possible to introduce any word other than the requested one to specify the context. This implied difficulties to isolate news with the desired meaning and long search times to avoid the ones using a particular term in a nonscientific alternative meaning.

«Elpais.com»: The search engine in this digital newspaper is quite simple so the searching process was time consuming. The list of results can be ordered by date or coincidence, first showing the news containing the searched word more often. For each term, we had to determine the threshold level of coincidence beyond which the system discriminated the news containing a concrete word from others containing words in the same lexical family (i.e. "infection", but not "infectious"). Once this threshold value had been established, we organized the list of news by coincidence value and counted the news items above the threshold in the interval 2009 to 2013.

In some terms the percentage of coincidence was not clearly defined. In those cases, the list of news items was ordered by date and we checked the news items one by one searching for the term in its scientific meaning. Again, we excluded news with the particular term having a non-scientific meaning. 


\section{Results and discussion}

\section{Pre-service primary teachers' knowledge of scientific concepts present in mass-media}

The global mean score (and standard deviation) for the group of participants was $\mathrm{X}=0.44(\mathrm{SD}=0.14)$. Quartiles were placed on $0.33,0.42$ and 0.52 scores. About $95 \%$ of the participants obtained an average between 0.16 and 0.71 and only 5 students scored over 0.70 . These results can be compared to the results obtained in the USA with a sample composed of science and social undergraduates $(X=0.54 ; \mathrm{SD}=0.17)$. Although our participants' global knowledge about the scientific terms included in MSL was unsatisfactory, according to the expected result in university students, it was not so different from the USA sample, which also included science students.

The instrument consistency was high enough as Kurder-Richardson's $20^{\text {th }}$-formula value was 0.71 . Further item analysis allowed us to appreciate items having high averages and others with very low averages. We also computed discrimination indexes, D, by means of the usual procedure: we considered the $27 \%$ of the upper global score (in MSL) sub-group of students, to the $27 \%$ of the lower global score sub-group of students. For each item, its D-value was obtained by subtracting the lower sub-group average from the upper sub-group average in this particular item. Twelve items resulted in $\mathrm{D}$ values under 0.30 , so having low discriminating power. Six of these 12 items were "difficult" items even for the high global score sub-group (upper sub-group score under 0.30) and 4 were "easy" items as the lower sub-group of students obtained high scores in them (lower sub-group score over 0.70 ). These 12 items obtained low item-total correlations and so, the participants' knowledge about these terms resulted in being disconnected from the rest in the instrument.

Table 1. Data obtained for each term

\begin{tabular}{lccc}
\hline \multicolumn{1}{c}{ Term } & Mean & SD & D-values \\
\hline Nova & .31 & .46 & .55 \\
\hline Genetic engineering & .19 & .39 & .23 \\
\hline Microprocessor & .22 & .42 & .30 \\
\hline Compact disc & .59 & .49 & .54 \\
\hline LSD & .25 & .43 & .53 \\
\hline Gill & .74 & .44 & .46 \\
\hline Aluminium & .24 & .43 & .42 \\
\hline Fiber optic & .03 & .18 & .09 \\
\hline
\end{tabular}

\begin{tabular}{llll}
\hline \multicolumn{1}{c}{ Term } & Mean & SD & D-values \\
\hline Proteins & .22 & .41 & .30 \\
\hline Nuclear weapons & .55 & .50 & .54 \\
\hline Tornado & .74 & .44 & .13 \\
\hline Lightning & .79 & .41 & .15 \\
\hline Sulphur & .53 & .50 & .48 \\
\hline Watt & .36 & .48 & .57 \\
\hline World Wide Web & .38 & .49 & .38 \\
\hline Electronic mail & .48 & .50 & .15 \\
\hline
\end{tabular}


José Javier Verdugo-Perona, Joan Josep Solaz-Portolés, Vicente Sanjosé

\begin{tabular}{llll}
\hline \multicolumn{1}{c}{ Term } & Mean & SD & D-values \\
\hline Bacteria & .08 & .27 & .20 \\
\hline Infection & .18 & .39 & .31 \\
\hline Irrigation & .58 & .50 & .10 \\
\hline Earthquake & .98 & .13 & .04 \\
\hline Hurricane & .50 & .50 & .40 \\
\hline Asbestos & .07 & .26 & .19 \\
\hline Moon & .96 & .19 & .11 \\
\hline Flora & .61 & .49 & .44 \\
\hline
\end{tabular}

\begin{tabular}{llll}
\hline \multicolumn{1}{c}{ Term } & Mean & SD & D-values \\
\hline Gram & .46 & .50 & .31 \\
\hline Petroleum/ Oil & .42 & .50 & .67 \\
\hline X-rays & .62 & .49 & .56 \\
\hline Satellite & .72 & .45 & .42 \\
\hline Solar energy & .26 & .44 & .11 \\
\hline Temperature & .10 & .30 & .08 \\
\hline Vaccination & .37 & .48 & .46 \\
\hline
\end{tabular}

\section{Presence of the scientific terms in Spanish digital newspapers}

Term frequency in the considered Spanish digital newspapers was not balanced in all cases: there were differences among the three newspapers in some terms, more frequent in one digital newspaper than in the others. Differences varied from just a few to several thousand and increased in those terms having more widespread use (e.g. "gram", "petroleum/oil" or "temperature"). Total item frequency was calculated by adding the frequencies in each newspaper. There were also great differences among terms, from $\mathrm{f}=48$ ("asbestos") to $\mathrm{f}=20678$ ("temperature") as some terms have extensive use and they were quite common in daily news, while others have appeared just in a few news stories in the last five years. Therefore, some of the scientific terms selected by Brossard and Shanahan as being very frequent in international important newspapers, have not been so frequent in the most read Spanish digital newspapers, in the 5-year period considered.

Figure 2 shows the accumulated term frequency in the considered digital newspapers. We split the terms in two groups ('high level' and 'low level' frequency) according to the median total frequency $(M=1286)$. It seemed appropriate to use the median instead of the average $(\mathrm{X}=3234)$, due to the wide range covered by the values, as an average is very sensible to extreme values. In fact, the standard deviation from frequency averages was also very high $(\mathrm{SD}=4462)$, greater than the mean value. This is a measure of the vast dispersion in frequency values.

Term frequency was distributed in a way that did not significantly differ from a normal distribution, according to the Kolmogorov-Smirnov test $(Z=1,322$; $\mathrm{p}=.061)$. However, the significance was marginal and close to the standard limit $(\mathrm{p}=.050)$. Taking this into account, together with the huge variability in the frequency, in some analyses we considered the logarithm of the frequency values as usual when data differences involved more than one order of magnitude. Log- 
frequency values distributed closer to a Gaussian curve (K-S; $\mathrm{Z}=0.623 ; \mathrm{p}=.833$ ) and ranked from 1.68 to 4.32 with an average (and SD) of 3.07 (0.72).

Figure 2. Term frequency in digital newspapers
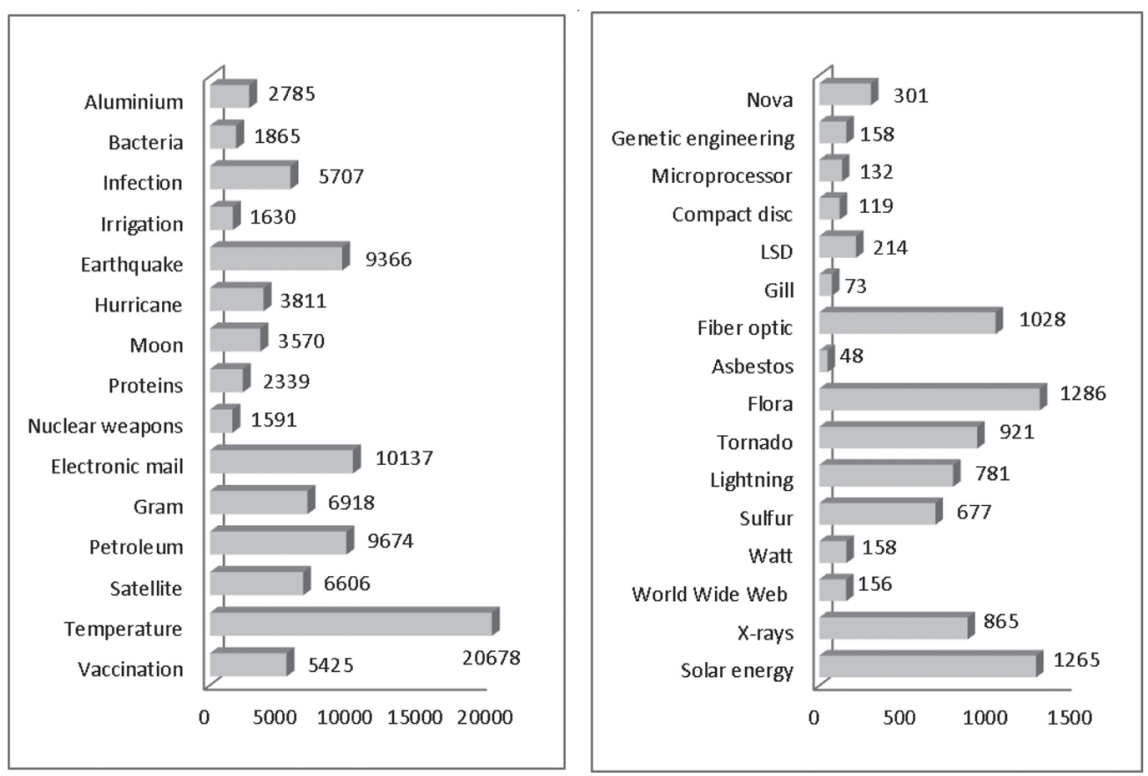

\section{Term frequency in digital newspapers as a predictor of scientific concept knowledge}

In order to contrast our second hypothesis, H2, we computed Pearson's correlation between the frequency, the log-frequency and the mean values for items in MSL (Table 2).

Table 2. Pearson's correlation between mean values for term knowledge and term frequency in digital newspapers

\begin{tabular}{lccc}
\hline & & frequency & Log-freq \\
\hline MSL-mean & $\mathrm{r}=$ & -.011 & .150 \\
\cline { 2 - 4 } & Sig. & .954 & .421 \\
\hline
\end{tabular}

In addition, we performed a less fine-grained analysis and classified the MSL terms in two groups, high/low frequency (Figure 2). Then, we studied whether 
or not these two groups obtained a different level of knowledge in our sample, according to the score in MSL. The level of term frequency did not have a significant influence on the mean scores for term knowledge $(\mathrm{t}(29)=-.398 ; \mathrm{p}=.694)$.

\section{Conclusions}

Our first hypothesis, H1, stated that pre-service primary teachers as educated people would show a high level of the knowledge of basic scientific terms, especially those frequently appearing in digital mass media. Data collected using Brossard and Shanahan's instrument (2006) did not confirm this hypothesis. Contrary to our expectations, the university students in the sample showed a level of knowledge (average of $44 \%$ of correct answers) lower than the one obtained by the authors in the USA from a sample including undergraduate science students (average 54\%). That means that our participants recalled the basic scientific terms included in the questionnaire in a worse way than they should do according to their education level, but perhaps not so far from the USA undergraduate non-science university students. Our result agrees with other recent study that has found a similar low level of scientific literacy in Spanish university students (Verdugo, Solaz-Portolés \& Sanjosé, 2014).

Therefore, our sample was particularly singular, or some of the terms asked about were not appropriate to our sample, or the scientific literacy in Spanish young educated university students, not specialised in sciences, should be seriously reconsidered.

Looking at particular items, some terms obtained quite low average values (cf. Table 1). This is the case of "Fiber optic" $(\mathrm{X}=0.03)$, "Asbestos" $(\mathrm{X}=0.07)$, "Bacteria" $(\mathrm{X}=0.08)$ and "Temperature" $(\mathrm{X}=0.10)$. The latter term is a special case. It is the most frequent term in the digital newspapers analysed (Figure 2), but despite its high presence, its formal scientific definition is not widely known by pre-service primary teachers, university students. This suggests low levels of comprehension monitoring when reading or learning science: these students are probably convinced they do know what temperature is (and other terms), without noticing that they are not able to give a correct definition.

Fortunately, scientific literacy also involves other kinds of knowledge, apart from concepts, but these results make us alert to university students' literacy, in particular, pre-service primary teachers.

We formulated another hypothesis, H2: If digital newspapers are considered by students as a source of science content information, then the more frequent a term or concept is in those newspapers, the higher the knowledge is among the participants of this term. In our sample, mean values for term knowledge were 
not correlated at all to term frequency or to log-frequency in the Spanish digital newspapers considered.

Thus, this result suggests that probably our students do not read digital newspapers as often as we expected, or if they read them these newspapers are not considered as a source of science education.

In summary, the participants, pre-service primary teachers, university students, have a lower level of basic scientific knowledge than they should have, and it seems that they do not use digital newspapers to improve their science education.

Only a few decades have passed since Tichenor, Donohue and Olien (1970) found a significant relationship between the flow of news in mass media and educated citizens' literacy. At that time, most of the newspapers readers were a minor part of society and they were also highly educated people. Nowadays, in the digital era, things seem to be different: information sources are at hand and are very easy to access by most people. However, their educational use is not straightforward and needs teachers' particular and conscious effort.

Even though digital mass media are frequently used by the new generations of students, and science teachers are using them as an instruction resource, special attention in instruction is needed to change students' use of those digital media from ludic to educational purposes. This implies including mass literacy in teacher education curricula as Torres and Mercado (2006) have pointed out. Kinds of literacy other than scientific literacy could benefit from this consideration, as well.

\section{References}

Álvarez, P. (2007). La prensa como recurso en educación ambiental: análisis de una experiencia ("Newspapers as a didactic resource for the environmental education"). Comunicar, 29, 165-172.

Aparici, R. (2005). Medios de Comunicación y Educación (“The media and education"). Revista de Educación, 338, 85-99.

Aufderheide, P. \& Firestone, C.M. (1993). Media literacy: a report of the national leadership conference on media literacy, Washington DC, Aspen Institute.

Brossard, D. \& Shanahan, J. (2006). Do they know what they read? Building a scientific literacy measurement instrument based on Science media coverage. Science Communication, 28, 47-63.

Brown, James A. (1998). Media literacy perspectives. Journal of Communications, 48, 44-56. Casero, A. (2012). Beyond Newspapers: News Consumption among Young People in the Digital Era. Comunicar, 39, 151-158. (DOI: 10.3916/C39-2012-03-05).

Gil, D. \& Vilches, A. (2006). Educación ciudadana y alfabetización científica: mitos 
y realidades ("Citizen education and scientific literacy: myths and realities"). Revista Iberoamericana de Educación, 42, 31-53.

Hobbs, R. \& Jensen, A. (2009). The past, present and future of media literacy education. Journal of Media Literacy Education, 1, 1-11.

Hurd, P.D. (1998). Scientific Literacy: New minds for a changing world. Science Education, $82,407-416$.

Ingle, H.T. (1974). Communication Media and Technology: A Look at Their Role in Nonformal Education Programs. Washington, D.C.: Information Center on Instructional Technology. Academy for Educational Development, Inc.

Isaacs, A., Daintith, J. \& Martin, E. (1999). A dictionary of science. Oxford: Oxford University Press.

López, P. (Coord.). La prensa escrita, recurso didáctico. Madrid. Ministerios de Educación, Cultura y Deporte; CIDE, 2003.

Kožuchová, M. (2010). Creating the socio-cultural model of scientific-technical literacy. The New Educational Review, 20, 109-119.

Martisson, J. (2009). The role of media literacy in the governance reform agenda. Washington, DC: World Bank Communication for Governance and Accountability Program.

Ronda, J. (2002). La formación de los docentes en comunicación desde la perspectiva de los comunicadores ("Teachers training on communication from communicators' perspective"). Comunicar, 18, 143-147.

Tichenor, P.J., Donohue, G.A., \& Olien, C.N. (1970). Mass Media Flow and Differential Growth in Knowledge. The Public Opinion Quarterly, 34, 159-170.

Torres, M. and Mercado, M. (2006). The need for critical media literacy in teacher education core curricula.

Educational Studies: A Journal of the American Educational Studies Association, 39, 260-282.

Verdugo, Solaz-Portolés \& Sanjosé, V. (2014). Spanish pre-service primary teachers' knowledge of science concepts: an instrument for its assessment. Submitted to Hacettepe University Journal of Education.

Wilson, C.; Grizzle, A; Tuazon, R.; Akyempong K. \& Cheung, Ch. (2011) Alfabetización Mediática e Informacional Curriculum para profesores. París: Unesco.

Wellington, J. (1991) Newspaper science, school science: friends or enemies? International Journal of Science Education, 13, 363-372, (DOI: 10.1080/0950069910130401). 